\title{
EFFECTS OF POLITICAL RISK FACTORS ON TAX REVENUE IN KENYA
}

\author{
Manyanza Rhodah Muenii, \\ Nelson H. Wawire, \\ Perez A. Onono \\ Department of Applied Economics, \\ School of Economics, Kenyatta University, \\ P.O Box 43844 -00100, \\ Nairobi, Kenya
}

\begin{abstract}
:
A broad range of tax reforms have been implemented in Kenya in the post-independence period with the objective of increasing tax revenue for promoting economic growth with reduced reliance on external funding. Most of the reforms have targeted broadening of the tax base. However, tax collections remain inadequate, and deficits have persisted. Past studies on tax revenue growth have looked at effects of foreign sector, stage of development, demographic factors and sectoral mix on tax revenue. The models used in those studies did not factor in political risk factors including democratic accountability, bureaucracy quality and internal conflict. Such factors can have significant direct or indirect influence on tax revenue. This study estimated tax revenue models with these factors captured using data for the period 1984 to 2016. The findings show that increase in bureaucracy quality and democratic accountability lead to increase in tax revenue. Efficiency of institutions is shown to enhance tax collections during periods of social strife suggesting the presence of displacement and inspection effect. Internal conflicts are shown to cause declines in tax revenues. The government of Kenya and its revenue authority should therefore strengthen the quality and efficiency of institutions and effective control measures on acts of civil war, terrorism and civil disorder alongside the tax reforms to increase tax revenues.
\end{abstract}

JEL: H20; H21; H25

Keywords: tax revenue, democratic accountability, bureaucracy quality, internal conflict

i Correspondence: email mueni.manynza@ku.ac.ke, manyanza2013@gmail.com 


\section{Introduction}

Tax performance and domestic revenue mobilisation (DRM) are critical for achievement of fiscal sustainability, reducing over reliance on external funding and reinforcement of a country's ownership of public policy. It also enhances the country's financial autonomy (Wawire, 2006; 2016; Bird, Martinez-Vazquez \& Torgler, 2008; African Development Bank [AfDB], Organization for Economic Cooperation and Development [OECD] and United Nations Development Programme [UNDP], 2016). Tax and non-tax revenues are therefore vital components that provide governments with the funds needed to invest in development. Efforts have been made to increase DRM in many developing countries by adopting tax policies to broaden the tax base. The policies include, right mix of different types of taxes and designing efficient tax systems, capacity building to fight domestic and foreign sources of tax base erosion, adhering to good administrative procedures by addressing capacity of institutions responsible for collecting taxes and promoting good governance in tax matters (OECD, 2015).

Various tax reforms have been implemented in Kenya with an objective of increasing DRM through broadening the tax base, improving efficiency and administration of revenue authorities. Some of the tax reforms undertaken in the country in the 1990's include; the tax administration reforms through establishment of Kenya revenue authority (KRA) in 1995 with autonomy in tax revenue administration; value added tax reforms, and income tax reforms.

The main objective of establishing the KRA was to improve efficiency and quality of services in tax administration towards increasing revenue collections, acquisition of skilled staff, ensuring effective use of automated system and the need to reduce tax evasion. The reforms were also meant to ensure maximum DRM in order to support economic and social development and to reduce overdependence on foreign aid (Wawire, 2006; AfDB, 2010).

VAT was introduced in the year 1990 to replace the sales tax at a rate of 18 per cent to address the fiscal challenges caused by low tax yields. The argument for the changes was that VAT had higher revenue potential and was easier to understand and interpret. The introduction of VAT was therefore meant to increase tax revenue by raising tax rates and broadening the tax base (Muriithi \& Moyi, 2003; Wawire, 2006; AfDB, 2010).

Widening of the tax base has also been pursued through income tax reforms. Income tax was introduced in 1937 and the main reforms in the 1990's included, reduction of the top marginal tax rate for individual tax which was levied at eight marginal rates ranging from 10 per cent to 65 per cent. In the year 1990 the top marginal rate of 65 per cent was reduced to 45 per cent, in 1996 to 35 per cent, while in 1998 it was reduced to 32.5 per cent and in the year 2000 it was reduced to 30 per cent until the year 2019 . The current rates for individual tax are 10, 15, 20, 25, and 30 per cent (Karingi, Wanjala, Nyamunga, Okello, Pambah \& Nyakang'o, 2005). However, as a result of the covid-19 pandemic the rates were reduced to 25 percent in the year 2020 (KRA, 2020). 
The main objective of the tax policy reforms and the discretionary changes was to mobilize more revenues for fiscal sustainability and maintaining budget deficits at sustainable levels (Osoro, 1993; KIPPRA, 2006). Despite the reforms the country still faces challenges in raising tax revenue. These challenges are thought to include, the presence of the hard-to-tax sectors, such as the agricultural sector, the small enterprises and the large informal sector which operates outside the reach of the tax law, weak administration and underground economy (Wawire, 2006; OECD, 2015). The trends of tax shares and budget balances as per cent of gross domestic product (GDP) in Kenya are shown in Figure 1 and Figure 2 respectively.

Figure 1: Tax to GDP in Kenya

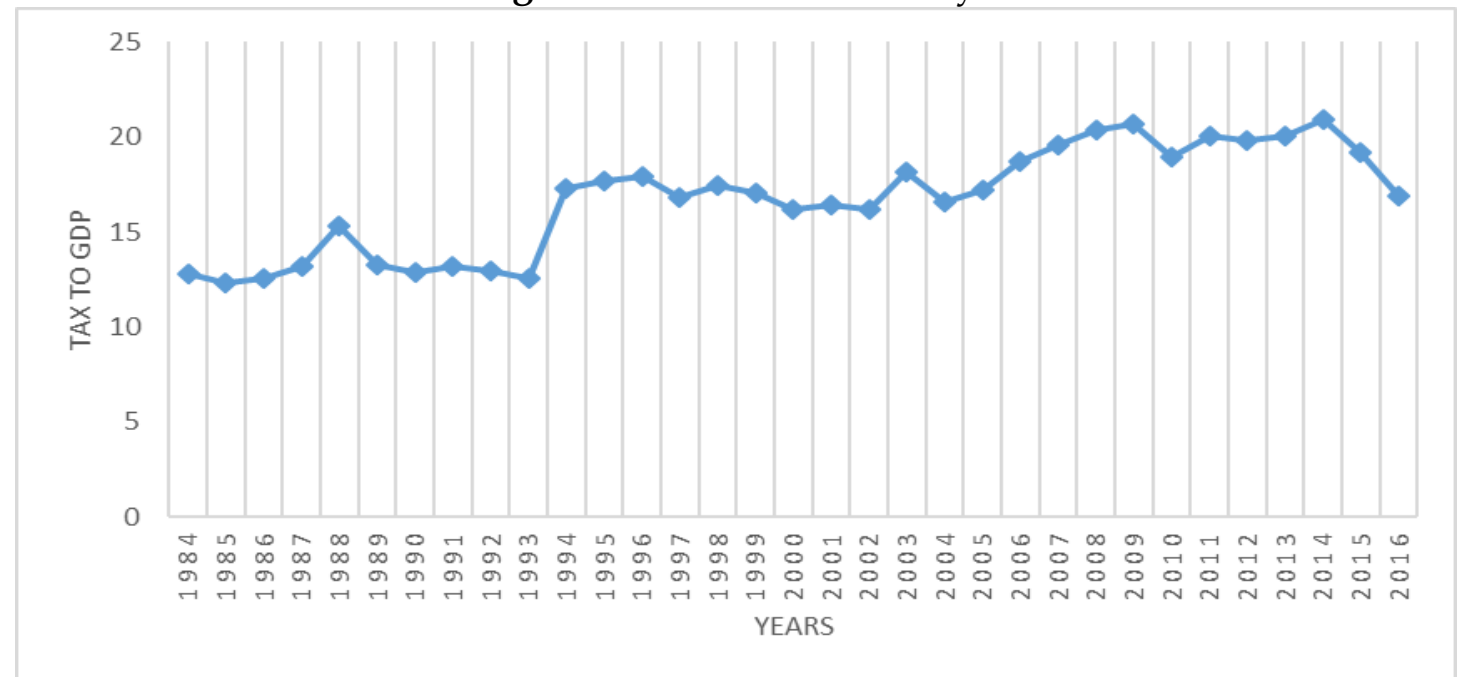

Source of Data: African Economic Outlook (2012 to 2016) and Mansour (2014): A Data Set for SSA

Figure 1: Budget balance excluding grants as a per cent of GDP in Kenya

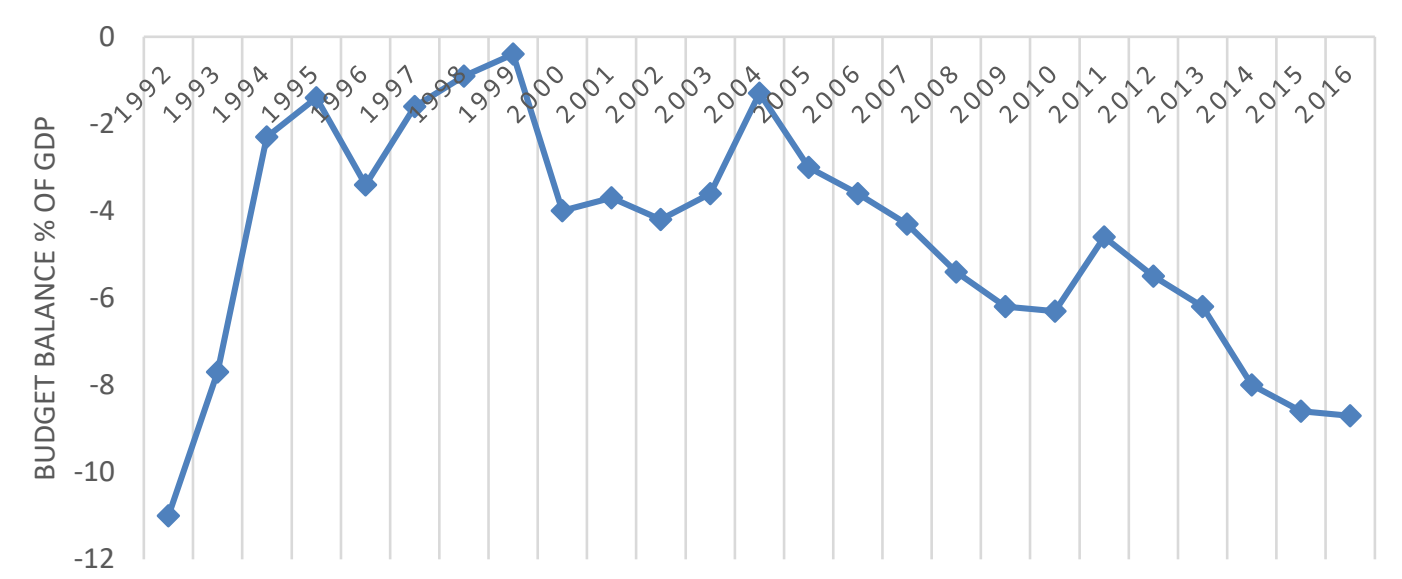

Source: Regional Economic Outlook SSA 2018; International Financial Statistics, IMF selected issues

As shown in Figure 1, the trend of tax shares in Kenya has been fluctuating from 1984 to 2016. There was a sharp increase in tax shares from 1993 to 1994 compared to the other years. The sharp increase in tax shares is attributed to increase in exports due to export support programmes, the improvements in tax revenue collection after establishment of Kenya revenue authority, full import liberalization (Muriithi \& Moyi, 
2003; Muthoga, 2003; wawire, 2006). On the other hand, the decline in tax shares from 2008 to 2010 is attributed to 2008/2009 financial crises and the spillover effects of postelection violence in the year 2008 due to acts of civil conflicts (Wawire, 2006; European Union, 2010). The year 1985 recorded the lowest tax share within the study period, this is as a result of financial crises which led to collapsing of many local banks (Muthoga, 2003). This implied that the quality of institutions and pro activeness of the government in providing checks and balances was inadequate. During this period, the Kenya revenue authority was yet to be formed.

Despite the increasing though fluctuating trend of tax shares in Kenya, the tax-toGDP ratio is still low, and the country has not been able to attain the Sub Saharan Africa (SSA) target of 26 per cent tax-to GDP average. This calls for the need to establish the determinants of tax revenue in Kenya focusing on the political risk factors (OECD, 2015; Kenya Institute for Public Policy Research and Analysis [KIPPRA], 2006).

From Figure 2 the trend of budget deficits in Kenya is quite volatile. The sharp declines in budget deficits shows increases in tax revenues whereas the increases in budget deficits is an indication of decline in tax revenues. Several factors were associated with decline in budget deficits for example, increase in tourism output, private sector investment mainly in the energy sector, political stability in a country, export promotion programmes, quality institutions and import liberalization (Republic of Kenya, 2000; Muthoga, 2003; European Union, 2010). On the other hand, decline in agricultural output due to drought, acts of civil disorder, increase in petroleum prices, financial crises due to lack of proper checks and balances by government leading to weak institutions and decline in coffee prices led to decline in tax revenues (Republic of Kenya, 2000). Tax reforms have been implemented in Kenya such as Value Added Tax (VAT), income tax and tax administration reforms. The persistent deficits show the inability of the tax system to generate sufficient revenues to finance public expenditure despite the reforms.

\section{Literature Review}

Wawire (1991) analysed factors that determine tax revenue in Kenya for the period 19581989. Regression approach was used in the study and the variables included in the study were international trade, mining share to GDP, manufacturing, agriculture and fishing share to GDP. The study findings revealed that international trade, mining and manufacturing increase the tax revenue while agriculture and fishing share to GDP showed an indirect relationship. The limitation of the study was that, only supply factors were considered and not the demand factors captured by political risk factors.

Stotsky and Woldemariam, (1997) conducted a study to examine determinants of tax revenue for 43 Sub Saharan African (SSA) countries, Kenya included for the period 1990 to 1995 . The study used the regression approach and the variables used in the study included share of mining, share of agriculture, per capita income, share of exports and share of imports to GDP. The findings showed that share of agriculture to GDP and mining in GDP were negatively related to tax revenue while export shares in GDP and per capita income were positively related to tax share. The study results revealed 
manufacturing share to GDP had a direct effect while mining share had an inverse effect with tax share. The current study also used the regression approach and filled the gap by establishing the effects of political risk factors on tax revenue.

Gupta (2007) used regression approach and investigated the determinants of tax revenue for 105 developing countries from 1980 to 2004. Both fixed effects and random effects specifications were used. The variables included in the model were, GDP per capita, share of manufacturing in GDP, share of agriculture in GDP, share of imports, debt and aid ratio. The study results showed that the coefficients of structural factors like GDP per capita, share of agriculture in GDP and trade openness were statistically significant. Foreign debt was found to be negatively related to revenue performance while corruption as a measure of institutional quality was not significant. This study used the regression approach but with data from the period from 1984 to 2016 . On institutional quality the study used the political risk factors including bureaucracy quality, democratic accountability and internal conflict.

Aloo (2012) examined the determinants of tax revenue in Kenya for the period 2007 to 2011 using the regression approach. The variables used in the study included GDP, tax rate, oil prices and exchange rates. The findings of the study showed that increase in exchange rate and upward change in oil prices increased tax revenues while increase in tax rates led to decline in tax revenues. The limitation of the study is the demand factors captured by political risk factors were not captured in the study.

Murunga (2014) investigated factors influencing tax revenue in Kenya for the period 1980-2012 using the regression approach. The variables used in the study included GDP per capita, broad money percent of GDP, import percent of GDP, agriculture share in GDP and external debt in GDP. The findings of the study revealed that size of monetary base, foreign aid tax and per capita GDP are significant determinants of tax effort and have a direct relationship. While share of agriculture in GDP and share of external debt in GDP are significant determinants but are inversely related to tax effort. The limitation of this study was that it only considered the supply side factors but no demand side factors were included proxied by the political risk factors.

Wawire (2017) examined the determinants of VAT in Kenya form the period $1963 / 64$ to $2008 / 09$ using the regression approach. The study results revealed that VAT was elastic with respect to GDP. The study focused more on how unusual circumstances and tax reforms influenced VAT. The study findings revealed that tax management measures like introduction of sales tax, establishment of Kenya revenue authority and establishment of tax management procedures led to increase in VAT. High petroleum prices, excess high rainfalls (EL Nino) and decline in output from tourism sector reduced VAT. The limitation of this study this study was that political risk factors which included democratic accountability, bureaucracy quality and internal conflict were not considered. Moreover, the study only looked at determinants of VAT while current study focused on determinants of amount of tax revenue

The current study, therefore, will examine the effects of political risk factors on tax revenue in Kenya for the period 1984 to 2016. The political risk factors are democratic accountability, bureaucracy quality and internal conflict. 


\section{Methodology}

\subsection{Theoretical Framework}

The paper seeks to establish the determinants of tax revenue in Kenya. Analysis is anchored on the classical theory of taxation as advocated by Ricardo in 1817 and Mill in 1848 (as cited in Shoup, 1958). The theory is generally concerned with what determines the taxable capacity or the maximum amount of tax that could be collected without affecting tax payer's standard of living of a country. The theory follows the basic or traditional supply side tax policy which recommended tax reforms to eliminate loopholes in tax system (Gandhi, 1987). The supply side economists also argued that tax performance in developing countries would be influenced by structural and institutional changes apart from fiscal policies (Gandhi, 1987; Howard, 2001; Clark, 1945). Following Clark (1945), Gandhi (1987) and Howard (2001) the maximum amount of tax that could be collected in a given period for a country is determined by structural factors (S), macroeconomic policies (M), institutional changes (INST) and tax bases (TB), to yield a general tax function given as in equation 3.1,

$$
T=f(S, I N S T, M, T B)
$$

Where, $\mathrm{T}$ is the tax revenue.

The structural factors (S) were characterised by composition of income sources and the foreign sector, where GDP per capita (GDPPC) is used to capture structural factors and trade openness (OP) as a proxy for the foreign sector. The institutional factors were captured mainly by the political risk factors, which included bureaucracy quality (BQ), democratic accountability (DA) and internal conflict (INC). The macroeconomic policies was proxied by inflation (INF). The tax base are sources of taxes such manufacturing (MS), mining (MN), agriculture (AGR), service (S) among others. Manufacturing share to GDP was used to capture the tax base. The study adopted equation (3.1) as adopted by Bahl (1971), Stotsky and Woldemariam (1997), Bird et al. (2008), Teera (2003) and Wawire (2003) who employed the regression approach to determine the maximum amount of tax that could be collected in a given period. Apart from political risk factors, other variables included in the model were GDP per capita, trade openness, manufacturing share in GDP, inflation and dependency ratio.

The specified model used in the study was expressed as in equation 3.2,

$$
T_{t}=f\left(G D P P C_{t}, O P_{t}, M S_{t}, B Q_{t}, D A_{t}, I N C_{t}, D R_{t}, I N F_{t}\right)
$$

Where, $T_{t}$ - is the actual tax revenue collections in a given period in the country. The country of study was Kenya and the scope was from 1984 to 2016. The independent variables are; $G D P P C_{t}$-GDP per capita, $O P_{t}$-trade openness, $M S_{t}$-manufacturing share in $\mathrm{GDP}, B Q_{t}$-bureaucracy quality, $I N C_{t^{-}}$internal conflict, , $D R_{t^{-}}$dependency ratio, $I N F_{t^{-}}$ inflation and $D A_{t}$-Democratic accountability. 


\subsection{Definition and Measurement of Variables}

Table 3.1: Definition and Measurement of Variables for Estimating Tax Revenue

\begin{tabular}{|c|c|c|}
\hline Variable & Definition & Measurement \\
\hline $\begin{array}{l}\text { Tax Revenue } \\
\left(T_{t}\right)\end{array}$ & $\begin{array}{l}\text { Total amount of tax collected by the } \\
\text { government during a given period }\end{array}$ & $\begin{array}{l}\text { Actual or measured tax revenue for } \\
\text { each country in its currency unit in a } \\
\text { given period }\end{array}$ \\
\hline $\begin{array}{l}\text { GDP PER Capita } \\
\left(G D P P C_{t}\right)\end{array}$ & $\begin{array}{l}\text { Average income per person in a } \\
\text { country }\end{array}$ & $\begin{array}{l}\text { Ratio of GDP to population in a given } \\
\text { year }\end{array}$ \\
\hline $\begin{array}{l}\text { Trade Openness } \\
\left(O P_{t}\right)\end{array}$ & $\begin{array}{l}\text { The extent to which a country is } \\
\text { open to trade }\end{array}$ & $\begin{array}{l}\text { Percentage of sum of exports and } \\
\text { imports to GDP for a country in a } \\
\text { given period }\end{array}$ \\
\hline $\begin{array}{l}\text { Manufacturing share } \\
\text { to GDP } \\
\left(M S_{t}\right)\end{array}$ & $\begin{array}{l}\text { The total value added from } \\
\text { manufacturing output as a share of } \\
\text { country's output }\end{array}$ & $\begin{array}{l}\text { Percentage of value added from } \\
\text { manufacturing to GDP for a country } \\
\text { in a given period }\end{array}$ \\
\hline $\begin{array}{l}\text { Bureaucracy Quality } \\
\left(B Q_{t}\right)\end{array}$ & $\begin{array}{l}\text { Strength and quality of institutions } \\
\text { and how they tend to minimise } \\
\text { revisions of policy when government } \\
\text { changes }\end{array}$ & $\begin{array}{l}\text { Bureaucracy Quality Index for a } \\
\text { country in a given period as reported } \\
\text { by ICRG }\end{array}$ \\
\hline $\begin{array}{l}\text { Dependency ratio } \\
\left(D R_{t}\right)\end{array}$ & $\begin{array}{l}\text { This is proportion of non-working } \\
\text { segment of a population to the } \\
\text { working segment }\end{array}$ & $\begin{array}{l}\text { Total number of people aged below } 14 \\
\text { years and above } 65 \text { years as a } \\
\text { Percentage of the total population in a } \\
\text { given period }\end{array}$ \\
\hline $\begin{array}{l}\text { Democratic } \\
\text { Accountability } \\
\left(D A_{t}\right)\end{array}$ & $\begin{array}{l}\text { A measure of how the government is } \\
\text { responsive to its people in terms of } \\
\text { providing checks and balances }\end{array}$ & $\begin{array}{l}\text { Democratic Accountability index for a } \\
\text { given period as reported by ICRG }\end{array}$ \\
\hline $\begin{array}{l}\text { Internal Conflict } \\
\left(I N T_{t}\right)\end{array}$ & $\begin{array}{l}\text { An indicator of political violence in } \\
\text { the country due to coup threat, civil } \\
\text { disorder or even terrorism }\end{array}$ & $\begin{array}{l}\text { Internal Conflict Index for a given } \\
\text { period as reported by ICRG }\end{array}$ \\
\hline $\begin{array}{l}\text { Inflation } \\
\left(I N F_{t}\right)\end{array}$ & $\begin{array}{l}\text { The general increase in prices of } \\
\text { goods and services in the country } \\
\text { during a given period of time }\end{array}$ & Inflation rate \\
\hline
\end{tabular}

\subsection{Data and Sources}

The study used secondary data which was obtained from Kenya economic surveys (various issues), World Development Indicators (WDI), International Country Risk Guide (ICGR) and African Economic Outlook, for the period 1984 to 2016. Data for actual tax revenue was converted to real terms by dividing the nominal values with inflation (consumer prices annual percentage). All variables were transformed to natural logarithms because log transformation makes distribution to be better behaved and reduces extremes in data thereby curtailing the effects of outliers (Benoit, 2011).

\section{Results and Discussions}

\subsection{Unit Root Test Results}

Unit root test was done using the Kwiatkowski Phillips Schmidt and Shin test (KPSS). KPSS (1992) test for stationarity of the data was used instead of Augmented Dickey-Fuller (ADF) because the ADF test cannot distinguish between highly persistent stationary 
processes from non- stationary processes (Shin \& Schmidt, 1992). The KPSS unit root test results for the logarithms of tax revenue, manufacturing share in GDP, GDP per capita, dependency ratio, trade openness, inflation, democratic accountability, bureaucracy quality and internal conflict for Kenya are presented in Table 4.1.

Table 4.1: Unit Root Tests Results on Data for Kenya

\begin{tabular}{|l|l|r|l|}
\hline Variable & Form of Test & $\tau$-statistic & Conclusion \\
\hline Log tax revenue & Trend\&Intercept & 0.057 & Stationary \\
\hline Log GDP per capita & Trend\&Intercept & 0.17 & Stationary \\
\hline Log manufacturing share & Trend\&Intercept & 0.08 & Stationary \\
\hline Log dependency ratio & Trend\&Intercept & 0.167 & Stationary \\
\hline Log democratic Accountability & Trend\&Intercept & 0.071 & Stationary \\
\hline Log trade openness & Trend\&Intercept & 0.102 & Stationary \\
\hline Logc inflation & Trend\&Intercept & 0.063 & Stationary \\
\hline Log bureaucratic quality & Trend\&Intercept & 0.106 & Stationary \\
\hline Log internal conflict & Trend\&Intercept & 0.145 & Stationary \\
\hline
\end{tabular}

Actual Critical Values: 0.216 (1\%), $0.416(5 \%)$

(Source of Data: Authors' calculations based on study data)

The unit root test results showed that all the series were stationary. This implies that a long run relationship between the log of tax revenue and the independent variables could be directly estimated by Ordinary Least Square (OLS) method. Estimation was therefore done and the model estimated was subjected to a series of diagnostic tests before it could be adopted for addressing the study's objectives.

\subsection{Diagnostic Tests results}

The diagnostic tests carried out included Normality tests, auto-correlation test, heteroscedasticity test, Ramsey RESET and CUSUM test. The CUSUM test result is presented in Figure 4.1, while the summary on the other diagnostic tests are presented in table 4.2 .

Table 4.2: Diagnostics Tests Results for the Determinants of Tax Revenue Model

\begin{tabular}{|c|c|c|c|c|c|c|c|}
\hline \multicolumn{2}{|c|}{ Jarque-Bera Statistic } & \multicolumn{2}{c|}{ Heteroskedasticity } & \multicolumn{2}{c|}{ Autocorrelation } & \multicolumn{2}{c|}{ Ramsey RESET } \\
\hline Jarque-Bera & P-Value & F-Statistic & P-Value & F-Statistic & P-Value & F-Statistic & P-Value \\
\hline 1.152 & 0.562 & 0.496 & 0.847 & 0.761 & 0.391 & 0.178 & 0.677 \\
\hline
\end{tabular}

From Table 4.2 the diagnostics test results show that the residuals are normally distributed, the variance of the error term is constant, there is no serial correlation in the residuals and the model has no misspecification error. This is because the probability values of all the tests is greater than 0.05 . This implied the model is fit to be adopted in achieving the objective. Figure 4.1 show the CUSUM test results. 


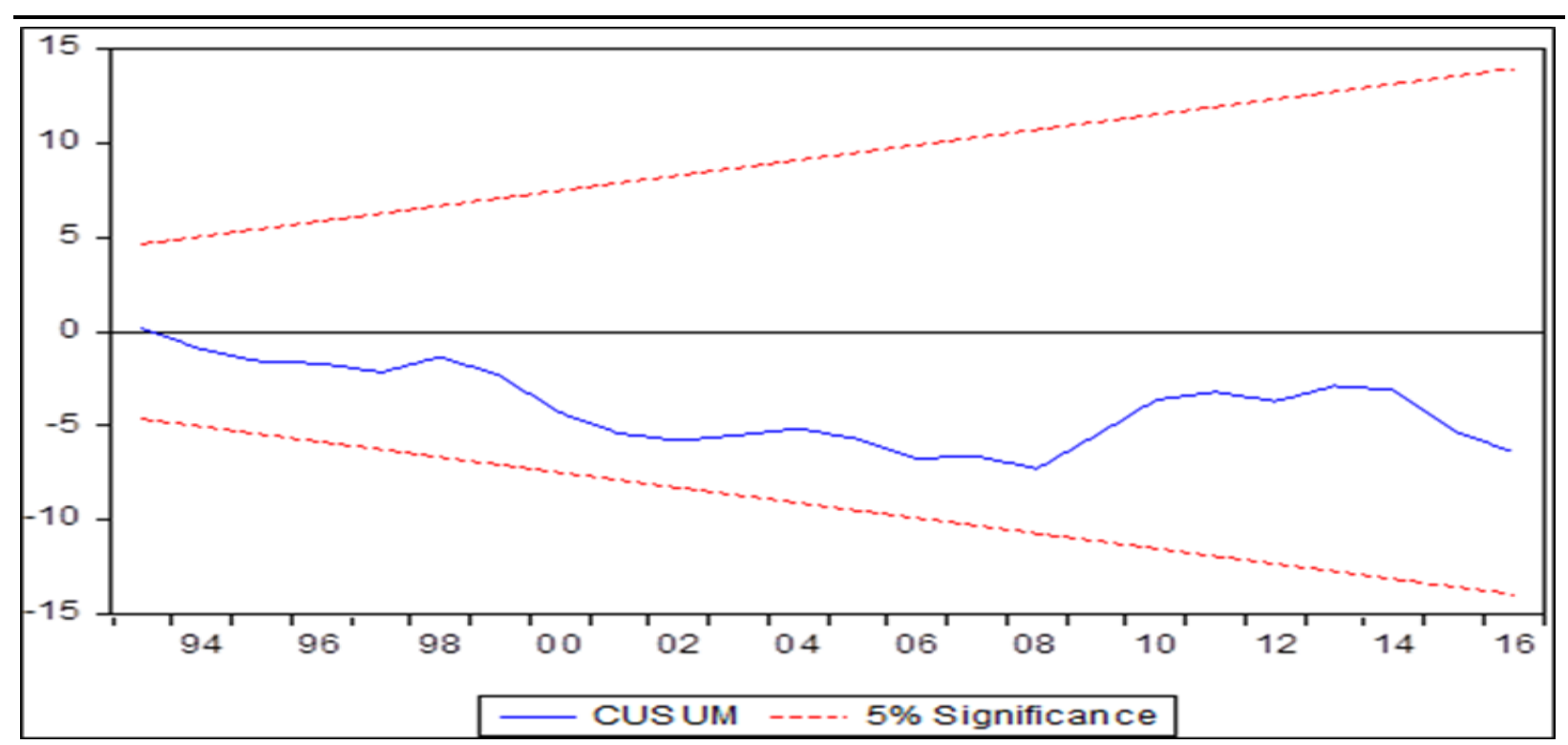

Figure 4.1: CUSUM Test for Tax Model of Determinants of Tax Revenue for Kenya

The CUSUM test results show that the cumulative sum of squares lies within the area between the two critical lines indicating that, the parameters of the model are stable for the sample period.

\subsection{Regression Results}

The findings of effects of political risk factors and other determinants on tax revenue in Kenya are presented in Table 4.3.

Table 4.3: Determinants of Tax Revenue for Kenya

\begin{tabular}{|l|l|}
\hline Dependent variable: Log of Tax Revenue & Coefficient \\
\hline Independent Variables & $46.109(13.811)$ \\
\hline Constant & $0.663^{* * *}(3.605)$ \\
\hline Log bureaucracy quality & $0.614^{* * *}(2.788)$ \\
\hline Log democratic accountability & $-8.899^{* * *}((-16.10)$ \\
\hline Log dependency ratio & $0.843^{* * *}(6.117)$ \\
\hline Log GDP per capita & $-0.893^{* * *}(-28.82)$ \\
\hline Log inflation & $-0.367(-1.602)$ \\
\hline Log internal conflict & $0.631^{* *}(2.146)$ \\
\hline Log trade openness & $-1.117^{* * *}(-4.720)$ \\
\hline Log manufacturing & $0.663^{* * *}(3.604)$ \\
\hline Interactive Term (BQIC) & $-1.0296^{* * *}(-2.897)$ \\
\hline Log internal conflict (IT Model) & 0.99 \\
\hline Adjusted R-squared & 869.003 \\
\hline F-statistic & 17 \\
\hline
\end{tabular}

Note: ${ }^{* * *}$ significant at $1 \% ;{ }^{* *}$ significant at $5 \%$; ${ }^{*}$ significant at $5 \%$; In parentheses are the $\mathrm{t}$-values; ITInteractive Term; BQIC- Bureaucracy Quality + Internal conflict;

Source of Data: Authors calculation from study data

From the estimation results the adjusted R-squared was 0.99. This indicates that 99 per cent of the variation in tax revenue is explained by variables included in the model. The effect of each of the determinants on tax revenue is discussed as follows, 


\section{a. Bureaucracy Quality}

The coefficient of bureaucracy quality was positive and statistically significant. The positive relationship implied that increase in bureaucracy quality increases tax revenue collection. The positive results suggest that, increase in strength and quality of institutions is very important in attracting citizens to support government functions through increase in tax revenues. The high-quality institutions ensure changes and revision of policies are minimal and government services are not interrupted. Therefore, through increased economic activities and broadening of tax base the tax revenues increase (Ehrhart, 2011). The stability in policy formulation and the day to day administrative functions, which enhance effectiveness in government spending, explains the positive relationship between bureaucracy quality and tax revenue in Kenya. The study findings are similar to those Javid and Arif (2012) for Asian countries where bureaucracy quality was a key determinant of increased tax revenues.

\section{b. Democratic Accountability}

The coefficient was positive and statistically significant. The results imply that how governments respond to the needs of its people is a key determinant of tax revenue in the country. This is because a country that is democratic is more peaceful and a model to the poor and middle class, hence fair redistribution of wealth and easier implementation of tax reforms and policies. Moreover, the response of government to interest groups in the country is also reduced by reducing tax exemptions which translates to increased tax revenues (Acemoglu and Robinson, 2006).

\section{c. Interactive Bureaucracy Quality and Internal Conflict (BQIC)}

The coefficient of BQIC (bureaucracy quality-internal conflict) was positive and statistically significant. The interactive term was meant to establish the inspection effect according to Peacock and Wiseman theory of public expenditure (Peacock \& Wiseman, 1961). The inspection effect implies that during periods of crises or disturbances there is requirement of upward revision of policies geared towards revenue mobilization in order to meet the increased expenditure during and after the crises. The review or revision of policies is made by both the government and the tax payers. This showed that the efficiency of institutions in Kenya is a key determinant of tax revenue in the country. The coefficient of internal conflict was negative and significant using the model with the interactive variable. This implied that internal conflict reduces the tax base in the country due to decline in economic activities. According to Onono (2016), inter-community conflicts lead to decline in economic activities due to decline in agricultural activities, destruction of infrastructure and capital flight which reduce the tax base. In Kenya for example we have the cases of inter- community conflict of 1992 and 2008 and the 1998 case of terrorism.

\section{d. Dependency Ratio}

The coefficient of dependency ratio was negative and statistically significant. The inverse relationship between tax revenue and dependency ratio implied that a one per cent 
increase in dependency ratio reduced tax revenue by 8.89 per cent. The argument is that increase in dependency ratio reduces future tax revenues due to reduction in number of tax payers as a result of increased old age population thereby reducing the productive population. It may also lead to decline in tax base due to low output as a result of reduced economic activities (Sriyana, 2011).

\section{e. GDP Per Capita}

The coefficient for log of GDP per capita was positive and statistically significant at one per cent level. The findings are similar to those of Bothole (2010) for SSA, Chelliah (1971) and Gupta (2007) for developing countries, Teera (2004) for Uganda and Wawire (1991) for Kenya. The argument for direct relationship between GDP per capita and tax revenue is that as a country develops, the formal sector of the economy grows. This calls for the need to improve all sectors of the economy, which calls for reforms both structural and judicial, which translates to increased demand for tax revenues (Ghura, 1998).

\section{f. Inflation}

The relationship between inflation and tax revenue was negative, which implied that increase in inflation reduces tax revenue. The inverse relationship may arise because increase in inflation may lead to erosion of business fundamentals which in turn leads to increase in cost of production. If producers are not able to pass the increased costs to the final consumers in terms of increased prices, the spillover effects is that producers are forced to engage in tax evasion and tax avoidance or even tax resistance, which in turn reduce tax revenues (Ade, Rossouw \& Gwatidzo, 2018)

\section{g. Trade openness}

The coefficient of trade openness was positive and statistically significant. The positive relationship may be attributed to the fact that taxation is simplified in an open economy, because as goods and services pass through the ports and borders, taxation for them by the customs authorities is readily done (Wawire, 1991). Moreover, trade openness may have exposed Kenya to new production technologies which in turn translated to higher productivity for firms and even at industry level, leading to increase in tax base (Aloo, 2017).

\section{h. Share of Manufacturing}

The inverse relationship between manufacturing share in GDP and tax revenue implies that, when manufacturing share in GDP increased by one per cent, tax revenue declined by 1.117 per cent. This inverse relationship of manufacturing share in GDP could be attributed to tax exemptions and the generous tax holidays geared towards boosting the manufacturing sector (Abdalaziz, 2012). The prolonged tax holidays could be a loophole to tax avoidance and could have negative effect on quality of investment and attracts mainly short term investments whose objective is profit making at the expense of long term investment with a goal of increased economic activity (Tanzi, 2001). 


\section{Recommendations}

Based on the findings of the study a number of policy implications have been suggested. The government, the revenue authorities and the judiciary should ensure recruitment of qualified personnel, ensure changes and revision of policies are minimal and stability in policy formulation. For efficiency and quality of institutions increases tax revenues. The government should also strengthen independence of the relevant institutions and avoid political interference in these institutions mainly KRA and judiciary, for proper checks and balances for this would lead to increase in tax collection. For the empirical results found that democratic accountability has positive influence on tax revenue. Therefore, how a government responds to needs of its people is important when it comes to DRM. The government should also put in place measures to maintain quality and efficiency in the institutions during periods of internal conflict. Measures to control acts of civil war, civil disorder and terrorism need to be put in place. For the inverse relationship between internal conflict and tax revenue using the interactive model imply reduced economic activities which in turn leads to reduced tax base.

The government of Kenya through Kenya Revenue Authority (KRA) should focus more on indirect taxes for example property taxes and exploit the large untaxed informal sector mainly the small-scale businesses in order to avoid heavy burden on working population. For increase in dependency ratio reduce tax revenue. Measures also need to be put in place by the government through national treasury to control inflation to manageable levels which will ease the high cost of production to producers. The government of Kenya through the Kenya Investment Authority (KIA) and Kenya revenue authority (KRA) should put in place policy measures to reduce tax exemptions and tax holidays to the manufacturing sector and measures to increase tax compliance. Regarding GDP per capita, the governments should embrace growth enhancing policies which will in turn increase income gains to individuals. For trade openness, the governments through the National Treasury need to encourage long term investments in capital intensive goods, maintain stable macroeconomic environment that is conducive for thriving investments and embrace new technology in the sectors producing goods for export. This is due to the positive relationship between trade openness and tax revenues.

For further areas of research, study should be carried out to establish whether other political risk factors for example socio economic conditions, government stability, external conflict and law and order influence tax revenue in Kenya.

\section{Conclusions}

The study investigated the effects of political risk factors, dependency ratio, GDP per capita, internal conflict, inflation, manufacturing share in GDP and trade openness on tax revenue. Bureaucracy quality, democratic accountability, GDP per capita and trade openness all led to increase in tax revenue, while dependency ratio, inflation and internal conflict lead to decline in tax revenues. The increase in bureaucracy quality during periods of conflict helps offset the negative effects of conflicts on revenues through 
inspection effect. The results indicate that efficiency of institutions enhance tax collections during periods of social strife.

\section{Conflict of Interest Statement}

The authors declare no conflicts of interests.

\section{About the Authors}

Rhodah Mueni Manyanza is a lecturer of Economics specializing in Public Sector Economics, International Economics, Planning and Evaluation in the School of Economics of Kenyatta University. She has eight years' experience in teaching and research at the university level. She holds a PhD in Economics and M.A (Economics) from Kenyatta University. She has carried out research on topics of taxation policy and investment.

Professor Nelson H. W. Wawire is a Full Professor of Economics specializing in Macroeconomics, Monetary Policy, Public Sector Economics, Project Appraisal, Planning and Evaluation and Women Economic Empowerment. He has over 28 years' experience in teaching, researching, consulting and offering community services at the University level. He is a reviewer for various International Journals, a resource person for the African Economic Research Consortium and a consultant for the World Bank, Centre for Global Development, and Government ministries and Departments. He has carried out research and published 41 articles, 8 books, 10 book chapters, five Policy briefs and two Country Notes on a wide range of topics and themes including but not limited to monetary policy, fiscal policy, Small Medium Enterprises, health economics and project evaluation.

Dr. Perez Ayieko Onono is a Senior Lecturer with 12 years of university teaching experience in the department of Applied Economics at the School of Economics of Kenyatta University. She is also the Dean of the School of Economics. She holds a PhD in Economics, and M.A (Economics) from Kenyatta University, Post Graduate Diploma in Education (PGDE) from Maseno University and BSc. in Agricultural Economics from Egerton University. Dr. Onono is an active consultant and researcher with a wide range of training and research experience in areas related to Human Development and Poverty analysis, Agricultural policy analysis, Agricultural productivity analysis, Taxation policy and fiscal decentralization.

\section{References}

Abdalaziz, M. (2012). Measuring taxable capacity in Libya. Doctoral dissertation. University of Gloucestershire.

Acemoglu, D., \& Robinson, J. A. (2006). Economic backwardness in political perspective. American political science review, 100(1), 115-131.

Ade, M., Rossouw, J., \& Gwatidzo, T. (2018). Determinants of tax revenue performance in the Southern African Development Community (SADC). Economic Research Southern Africa, ERSA working paper 762. 
African Development Bank, (2010). Domestic Resource Mobilization for Poverty Reduction in East Africa: Uganda Case Study. Regional Department East Africa (OREA). November.

African Development Bank [AfDB], Organization for Economic Cooperation and Development [OECD] \& United Nations Development Programme [UNDP], 2016). African Economic Outlook 2016. Sustainable Cities and Structural Transformation. Paris: OECD Publishing., No. 6(1), 21-37.

Aloo, L. O. (2017). Free Movement of Goods in the EAC. In East African Community Law (pp. 303-325). Brill Nijhoff.

Bahl, R. W. (1971). A regression approach to tax effort and tax ratio analysis. Staff Papers, No. 18(3), 570-612.

Bird, R. M., Martinez-Vazquez, J., \& Torgler, B. (2008). Tax Effort in Developing Countries and High-Income Countries: The Impact of Corruption, Voice and Accountability. Economic Analysis and Policy, No. 38(1), 55-71.

Botlhole, T. D. (2010). Tax Effort and the Determinants of Tax Ratio in Sub-Sahara Africa. An International Conference on Applied Economics-ICOAE. No. 110-113.

Chelliah, R. J. (1971). Trends in Taxation in Developing Countries, IMF Staff Papers, No. 2 (18), 254-325.

Clark, C. (1945). Public finance and changes in the value of money. The Economic Journal, No. 55(220), 371-389.

Ehrhart, H. (2011). Assessing the relationship between democracy and domestic taxes in developing countries. https://halshs.archives-ouvertes.fr/halshs-00553607; Accessed 21-08-2019.

European Union, (2010). An assessment of the response to the 2008- 2009 drought in Kenya. A report to the European Union Delegation to the Republic of Kenya

Gandhi, V. (1987). Tax reform: some considerations and limits (Lessons from experiences of developing countries). Seminar paper, University of the West Indies, St Augustine, Trinidad, November 1987.

Ghura, D. (1998). Tax Revenue in Sub-Saharan Africa: Effects of Economic Policies and Corruption. IMF Working Paper 98/135. Washington: International Monetary Fund.

Gupta, A. S. (2007). Determinants of Tax Revenue Efforts in Developing Countries, IMF Working Paper, No: WP/07/184 (July).

Howard, M. (2001). Public Sector Economics for Developing Countries. Canada. University of West Indies Press.

Javid, A. Y., Arif, U., \& Arif, A. (2011). Economic, political and institutional determinants of budget deficits volatility in selected Asian countries. The Pakistan Development Review. 50(4) 649-662.

Karingi S., Wanjala, B., Nyamunga, J., Okello, A., Pambah, E. and Nyakang'o, E. (2005). Tax reform experience in Kenya. Kippra Working paper, No.13. Nairobi. Kenya Institute for public policy research and analysis. 
Kenya Institute for Public Policy Research and Analysis (KIPPRA) (2006). Lessons from Kenya's tax reforms experience. Policy Brief No. 10. Nairobi: Kenya Institute of Public Policy Research and Analysis.

Muriithi, M. K. \& Moyi, E. D. (2003). Tax Reforms and Revenue Mobilization in Kenya, AERC Research Paper 131, Nairobi: AERC

Muthoga, S. K. (2003). Determinants of Foreign Direct Investment (FDI) in Kenya. Unpublished Master's Project. Kenyatta University.

Onono, P. (2016). Economic Effects of Inter-Community Conflicts in Kenya: Evidence of the Importance of Peace in the Realization of Sustainable Development. International Journal of Cooperation \& Development. 3(2): 118-129

Organization for Economic Cooperation and Development [OECD] (2015). Examples of Successful DRM Reforms and the Role of International Co-operation. Discussion Paper, July.

Peacock, A. T., \& Wiseman, J. (1961). Front matter, the growth of public expenditure in the United Kingdom. In The growth of public expenditure in the United Kingdom (pp. 32-0). Princeton. Princeton University Press.

Shin, Y., \& Schmidt, P. (1992). The KPSS stationarity test as a unit root test. Economics Letters, 38(4), 387-392.

Shoup, C. S. (1957). Ricardo and Taxation. Finanz Archiv/Public Finance Analysis, (H. 1), 1324.

Sriyana, J. (2011). The effect of budget deficit shock on government spending: an empirical case in Indonesia. International Journal of Business and Development Studies. 3(1) 41-58.

Stotsky, J. G. \& Wolde Mariam, A. (1997). Tax Effort in Sub-Saharan Africa. Washington, DC. IMF Working Paper.

Tanzi, V. (2001). Creating effective tax administration; the experience of Russia and Georgia. Pp. 53-74 in Kornai, Haggard, and Kaufman (2001)

Teera, J. M. (2003). Could Do Better: An Appraisal of Uganda's Tax performance relative to Sub-Saharan Africa'. Online: University of Bath: www.bath.ac.uk/cpe/workingpapers/Uganda-tax performance.pdf.

Wawire, N. H. W. (1991). An Empirical Assessment of Tax Performance in Kenya: 1958 1989, M.A Research Paper, Kenyatta University.

Wawire, N. H. W. (2006). Determinants of Tax Revenues in Kenya, Unpublished PhD Thesis, Kenyatta University.

Wawire, N. H. (2016). Analysis of Income Tax System Productivity in Kenya. Amity Journal of Economics. 1(2), (1-8)

Wawire, N. (2017). Determinants of value added tax revenue in Kenya. Journal of Economics Library, 4(3), 322-344. 


\section{Appendix}

Table A1: Determinants of Tax Revenue for Kenya Dependent Variable: Log Tax revenue Method: Least Squares Date: 11/05/18 Time: 12:29 Sample: 19842016 Included observations: 33

\begin{tabular}{|l|r|r|r|r|}
\hline Variable & Coefficient & Std. Error & t-Statistic & Probability \\
\hline C & 46.10893 & 3.338486 & 13.81133 & 0 \\
\hline Log bureaucracy quality & 0.662817 & 0.183878 & 3.604654 & 0.0014 \\
\hline Log democratic accountability & 0.614034 & 0.220236 & 2.788069 & 0.0102 \\
\hline Log dependency ratio & -8.899042 & 0.552605 & -16.1038 & 0 \\
\hline Log GDP per capita & 0.84296 & 0.137796 & 6.117436 & 0 \\
\hline Log inflation & -0.893083 & 0.030985 & -28.823 & 0 \\
\hline Log internal conflict & -0.366741 & 0.228902 & -1.602173 & 0.1222 \\
\hline Log manufacturing & -1.116807 & 0.236605 & -4.720136 & 0.0001 \\
\hline Log trade openness & 0.631244 & 0.294107 & 2.146306 & 0.0422 \\
\hline R-squared & 0.99656 & Mean dependent var & 9.550157 \\
\hline Adjusted R-squared & 0.995413 & S.D. dependent var & 1.708504 \\
\hline S.E. of regression & 0.115714 & Akaike info criterion & -1.248385 \\
\hline Sum squared resid & 0.321355 & Schwarz criterion & -0.840246 \\
\hline Log likelihood & 29.59834 & Hannan-Quinn criter. & -1.111058 \\
\hline F-statistic & 869.0028 & Durbin-Watson stat & 1.670959 \\
\hline Prob(F-statistic) & 0 & & \\
\hline
\end{tabular}

Table A2: Determinants of Tax Revenue for Kenya with Interactive Term Dependent Variable: LOGTAX_REVENUE Method: Least Squares Sample: 19842016 Included observations: 33

\begin{tabular}{|l|c|c|c|c|}
\hline Variable & Coefficient & Std. Error & t-Statistic & Prob. \\
\hline C & 46.10895 & 3.338485 & 13.81134 & 0 \\
\hline LOG_DEMOCTATIC_ACCOUNTABILITY & 0.614036 & 0.220236 & 2.788077 & 0.0102 \\
\hline LOG_DEPENDENCY_RATIO & -8.899044 & 0.552605 & -16.10381 & 0 \\
\hline LOG_INFLATION & -0.893083 & 0.030985 & -28.82302 & 0 \\
\hline LOG_MANUFACTURING & -1.116806 & 0.236605 & -4.720138 & 0.0001 \\
\hline LOGINTERNAL_CONFLICT & -1.02956 & 0.355437 & -2.8966 & 0.0079 \\
\hline LOGBQIC & 0.662817 & 0.183878 & 3.604656 & 0.0014 \\
\hline LOGGDP_PER_CAPITA & 0.842959 & 0.137796 & 6.117432 & 0 \\
\hline LOGTRADE_OPENNESS & 0.631244 & 0.294107 & 2.146305 & 0.0422 \\
\hline R-squared & 0.99656 & Mean dependent var & 9.550157 \\
\hline Adjusted R-squared & 0.995413 & S.D. dependent var & 1.708504 \\
\hline S.E. of regression & 0.115714 & Akaike info criterion & -1.248386 \\
\hline Sum squared resid & 0.321355 & Schwarz criterion & -0.840247 \\
\hline Log likelihood & 29.59836 & Hannan-Quinn criter. & -1.11106 \\
\hline F-statistic & 869.0038 & Durbin-Watson stat & 1.670958 \\
\hline Prob(F-statistic) & 0 & \multicolumn{4}{|l}{} & \\
\hline
\end{tabular}


Manyanza Rhodah Mueni, Nelson H. Wawire, Perez A. Onono

EFFECTS OF POLITICAL RISK FACTORS ON TAX REVENUE IN KENYA

Creative Commons licensing terms

Authors will retain copyright to their published articles agreeing that a Creative Commons Attribution 4.0 International License (CC BY 4.0) terms will be applied to their work. Under the terms of this license, no permission is required from the author(s) or publisher for members of the community to copy, distribute, transmit or adapt the article content, providing a proper, prominent and unambiguous attribution to the authors in a manner that makes clear that the materials are being reused under permission of a Creative Commons License. Views, opinions and conclusions expressed in this research article are views, opinions and conclusions of the author(s). Open Access Publishing Group and European Journal of Economic and Financial Research shall not be responsible or answerable for any loss, damage or liability caused in relation to/arising out of conflict of interests, copyright violations and inappropriate or inaccurate use of any kind content related or integrated on the research work. All the published works are meeting the Open Access Publishing requirements and can be freely accessed, shared, modified, distributed and used in educational, commercial and non-commercial purposes under a Creative Commons Attribution 4.0 International License (CC BY 4.0). 